Security of Computer Based Information Systems 


\section{Macmillan Computer Science Series}

Consulting Editor

Professor F. H. Sumner, University of Manchester

S. T. Allworth, Introduction to Real-time Software Design

Ian O. Angell, A Practical Introduction to Computer Graphics

R. E. Berry and B. A. E. Meekings, $A$ Book on $C$

G. M. Birtwistle, Discrete Event Modelling on Simula

T. B. Boffey, Graph Theory in Operations Research

Richard Bornat, Understanding and Writing Compilers

J. K. Buckle, The ICL 2900 Series

J. K. Buckle, Software Configuration Management

J. C. Cluley, Interfacing to Microprocessors

Robert Cole, Computer Communications

Derek Coleman, $A$ Structured Programming Approach to Data

Andrew J. T. Colin, Fundamentals of Computer Science

Andrew J. T. Colin, Programming and Problem-solving in Algol 68

S. M. Deen, Principles and Practice of Database Systems

P. M. Dew and K. R. James, Introduction to Numerical Computation in Pascal

M. R. M. Dunsmuir and G. J. Davies, Programming the UNIX System

K. C. E. Gee, Introduction to Local Area Computer Networks

J. B. Gosling, Design of Arithmetic Units for Digital Computers

Roger Hutty, Fortran for Students

Roger Hutty, Z80 Assembly Language Programming for Students

Roland N. Ibbett, The Architecture of High Performance Computers

P. Jaulent, The 68000 - Hardware and Software

M. J. King and J. P. Pardoe, Program Design Using JSP - A Practical Introduction

H. Kopetz, Software Reliability

E. V. Krishnamurthy, Introductory Theory of Computer Science

Graham Lee, From Hardware to Software: an introduction to computers

A. M. Lister, Fundamentals of Operating Systems, third edition

G. P. McKeown and V. J. Rayward-Smith, Mathematics for Computing

Brian Meek, Fortran, PL/I and the Algols

Derrick Morris, An Introduction to System Programming - Based on the PDP11

Derrick Morris and Roland N. Ibbett, The MUS Computer System

C. Queinnec, LISP

John Race, Case Studies in Systems Analysis

W. P. Salman, O. Tisserand and B. Toulout, FORTH

L. E. Scales, Introduction to Non-Linear Optimization

P.S. Sell, Expert Systems - A Practical Introduction

Colin J. Theaker and Graham R. Brookes, A Practical Course on Operating Systems

M. J. Usher, Information Theory for Information Technologists

B. S. Walker, Understanding Microprocessors

Peter J. L. Wallis, Portable Programming

I. R. Wilson and A. M. Addyman, A Practical Introduction to Pascal with BS 6192, second edition 


\title{
Security of Computer Based Information Systems
}

\author{
V.P. Lane \\ Principal Lecturer \\ Department of Systems and Computing \\ North East London Polytechnic
}

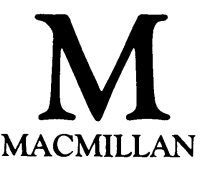


๑V.P. Lane 1985

All rights reserved. No reproduction, copy or transmission of this publication may be made without written permission.

No paragraph of this publication may be reproduced, copied or transmitted save with written permission or in accordance with the provisions of the Copyright Act 1956 (as amended).

Any person who does any unauthorised act in relation to this publication may be liable to criminal prosecution and civil claims for damages.

First published 1985

Published by

MACMILLAN EDUCATION LTD

Houndmills, Basingstoke, Hampshire RG21 2XS

and London

Companies and representatives

throughout the world

British Library Cataloguing in Publication Data

Lane, V. P.

Security of computer based information systems.

-(Macmillan computer science series)

1. Electronic data processing departments-

Security measures

I. Title

$658.4^{\prime} 78$

HF 5548.2

ISBN 978-0-333-36437-6

ISBN 978-1-349-18011-0 (eBook)

DOI 10.1007/978-1-349-18011-0 


\section{Contents}

Preface viii

Acknowledgements $x i$

1 Threats, Safeguards and Security Objectives 1

1.1 Security 1

1.2 An introduction to security of computer based information systems 2

$\begin{array}{ll}1.3 \text { Breaches of security } & 4\end{array}$

1.4 Threats, countermeasures and security functions 5

$\begin{array}{ll}1.5 \text { Sensitivity of applications } & 6\end{array}$

1.6 Definitions $\quad 8$

$\begin{array}{ll}1.7 \text { Summary } & 10\end{array}$

Questions 11

2 Physical Security 13

$\begin{array}{ll}2.1 \text { Natural disasters and intruders } & 13\end{array}$

$\begin{array}{ll}2.2 \text { Natural disasters } & 14\end{array}$

$\begin{array}{ll}2.3 \text { Access control and intruders } & 18\end{array}$

2.4 Conclusion $\quad 20$

$\begin{array}{ll}\text { Questions } & 21\end{array}$

3 Data Security 23

3.1 Threats to data 23

3.2 Security at the user-computer interface 24

3.3 Control of access to data 30

3.4 Control of flow $\quad 36$

3.5 Inference controls $\quad 38$

3.6 Cryptography 43

3.7 Conclusion $\quad 50$

Questions $\quad 51$

4 The Security Role of Components of Computer Configurations 54

$\begin{array}{ll}4.1 \text { Hardware } & 55\end{array}$

4.2 System software $\quad 59$

4.3 Security functions of an operating system 60

4.4 Verification of software, the kernel concept and 
$\begin{array}{ll}\text { penetration tests } & 64\end{array}$

$\begin{array}{ll}4.5 \text { Communications } & 64\end{array}$

4.6 Terminals, distributed data processing and the impact on $\begin{array}{ll}\text { security of online systems } & 67\end{array}$

$\begin{array}{ll}4.7 \text { Summary } & 72\end{array}$

$\begin{array}{ll}\text { Questions } & 73\end{array}$

5 People and Security $\quad \mathbf{7 5}$

5.1 The involvement of people in security $\quad 75$

$\begin{array}{ll}5.2 \text { Protection from employees } & 76\end{array}$

5.3 A company policy for recruitment, assessment and
termination of employment

$\begin{array}{ll}5.4 \text { Protection of employees } & 85\end{array}$

$\begin{array}{ll}5.5 \text { Employees as security safeguards } & 86\end{array}$

$\begin{array}{ll}5.6 \text { Summary } & 89\end{array}$

$\begin{array}{lr}\text { Questions } & 89\end{array}$

6 Implementing Security Controls in Applications Software During the Design and Build Phases

6.1 Management, users and security safeguards 92

6.2 The management and organisational environment 94

$\begin{array}{ll}\text { 6.3 Design methods } & 94\end{array}$

6.4 Controls within application software and at the
interface of the software

$\begin{array}{ll}6.5 \text { Summary } & 103\end{array}$

$\begin{array}{ll}\text { Questions } & 104\end{array}$

7 Security Aspects of the Operation of Computer Facilities 105

$\begin{array}{ll}7.1 \text { Operational security and the use of logs } & 105\end{array}$

7.2 Approaches to the operation of computer facilities 106

$\begin{array}{ll}7.3 \text { Operations staff } & 107\end{array}$

$\begin{array}{ll}7.4 \text { Library management system } & 107\end{array}$

$\begin{array}{ll}7.5 \text { Short term recovery } & 108\end{array}$

7.6 Maintenance of software and hardware $\quad 110$

$\begin{array}{lll}7.7 \text { Summary } & 111\end{array}$

Questions $\quad 111$

8 Developing and Reviewing a Security Programme of an Organisation

$\begin{array}{ll}8.1 \text { Risk management } & 112\end{array}$

8.2 Risk identification - a responsibility of management 115

$\begin{array}{ll}8.3 \text { Risk analysis } & 115\end{array}$

$\begin{array}{ll}8.4 \text { Courtney risk analysis } & 117\end{array}$

$\begin{array}{ll}8.5 \text { Heuristic methods as aids to risk analysis } & 122\end{array}$

8.6 Reviewing security in an organisation or initiating a 
security programme

$\begin{array}{ll}8.7 \text { Contingency planning } & 126\end{array}$

$\begin{array}{ll}8.8 \text { Summary } & 127\end{array}$

$\begin{array}{ll}\text { Questions } & 128\end{array}$

9 Privacy and Data Protection Legislation 130

9.1 Privacy concepts and the impact of information technology 130

9.2 Privacy events during the 1970s in the United Kingdom 132

$\begin{array}{ll}\text { 9.3 The international scene } & 135\end{array}$

$\begin{array}{ll}9.4 \text { Areas of concern } & 136\end{array}$

$\begin{array}{ll}9.5 \text { Legislation } & 137\end{array}$

$\begin{array}{ll}9.6 \text { Summary } & 141\end{array}$

Questions 142

10 Protection of Proprietary Software 144

$\begin{array}{lll}10.1 \text { The case for protection } & 144\end{array}$

10.2 Methods for protection of proprietary software 145

$\begin{array}{ll}10.3 \text { Copyright law } & 145\end{array}$

$\begin{array}{ll}10.4 \text { Patent law } & 148\end{array}$

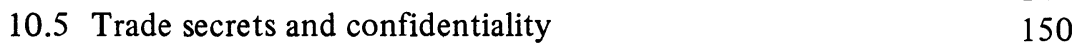

10.6 International cooperation and copyright reform 150

10.7 Protection by technical contrivance 153

10.8 Conclusions 154

Questions 154

11 Illustrative Examples of Breaches of Security 155

$\begin{array}{ll}11.1 \text { A privacy incident } & 155\end{array}$

11.2 Non-computer personnel and insecurity of
information systems

11.3 Mis-use of computer in an insurance company 158

11.4 Computer personnel steal files and demand ransom 160

11.5 Boiler explosion destroys computer office suite 161

$\begin{array}{ll}11.6 \text { Case study lessons } & 162\end{array}$

Questions 166

$\begin{array}{lll}12 & \text { Postscript } & 168\end{array}$

$\begin{array}{ll}12.1 \text { A company plan } & 169\end{array}$

12.2 Qualitative judgements and a systems approach 169

$\begin{array}{ll}12.3 \text { Microcomputers } & 170\end{array}$

$\begin{array}{ll}12.4 \text { A good design is a secure system } & 171\end{array}$

$\begin{array}{ll}\text { Questions } & 172\end{array}$

$\begin{array}{ll}\text { References and Bibliography } & 174\end{array}$

$\begin{array}{ll}\text { Index } & 180\end{array}$ 


\section{Preface}

Today, computer based information systems play a critical role and integral part in business operations. Companies and governments are involved each day with the electronic transfer of highly sensitive personal data and of data representing billions of pounds. Irrespective of whether or not a company is involved in electronic funds transfer, it is apparent that information is an important and valuable resource of small and medium sized businesses as well as large ones. These and other factors, such as data protection legislation, have combined to raise the subject of security of computer systems and computer based information systems to its current level of concern.

This book presents methods for engineering security into computer based information systems. It is not a computer security handbook because there are good handbooks already written; nor does it try to use checklists to show how to provide better levels of security. Instead, it attempts to show the underlying general principles of security. For example, checklists that are used extensively throughout the computer security industry are not shown in the book, but are discussed and explained as part of other heuristic methods.

A universal problem with books on computer security is that the subject embraces a vast number of topics, including physical security of buildings and computer facilities, fire protection, privacy, software, hardware, personnel management, financial control and audit and the psychological and sociological behaviour of people. As a result, some topics must be left in the background. Also authors may write on the subject from different viewpoints. For example, one author may concentrate on crime incidents, another on database security and another on hardware. My approach is from the educational needs of students aspiring to be systems analysts - an approach that naturally has its own strengths and weaknesses - but clearly this book can give only a broad insight into an extremely complex subject.

\section{Structure of the book}

Chapter 1 defines the basic terminology of security of computer based information systems and argues the importance of the subject. Chapter 2 summarises the basic concepts of physical security. Chapter 3 discusses the security of data within the computer and at the man-machine interface through consideration of access 
control, information flow, inference control in databases and cryptography. The highly specialised subjects of hardware, system software and communications are introduced in chapter 4 but only in so far as they influence computer applications. Chapter 5 explains the critical part played by people in security people represent both threats and safeguards. In chapter 6 the steps that must be followed to create and build secure application software are examined. Chapter 7 considers operational aspects of security and shows how operational procedures can ensure that well-designed application software does not deteriorate when in operation. Chapter 8 shows how a security programme can be developed for an organisation and stresses the critical role of people - a theme developed earlier in chapter 5. The historical and international background of the UK Data Protection Act with its management, technical and financial implications is reviewed in chapter 9. In chapter 10 the need for both technical and legal deterrents for proprietary software protection is stressed and detailed consideration is given to copyright, trade secret and patent protection. A number of real-life security breaches are described in chapter 11 to highlight points made in earlier parts of the book. One incident is used for a discussion of data protection legislation and the other incidents highlight the importance of contingency planning, company internal controls, recruitment procedures and policies on the use of computer resources by computer centre personnel. The final chapter refers to the need for a holistic approach to security and looks at the security implications of microcomputers.

\section{Suggestions to readers}

I have in mind one major group of readers, namely students who in their future careers will design information systems or advise non-computer personnel of a company about security. For these students the book provides a conceptual framework plus an explanation of useful principles and techniques. However, the book should be useful to any reader with a technical background and a serious interest in computing.

To facilitate its use as a textbook, questions are given at the end of each chapter. Pointers to answers are available from the author in a separate document. The majority of questions can be undertaken by a student studying alone, or they can be used for class discussion. There are a few questions, marked 'group problem', which are best studied by three or four students working together.

\section{For the student}

The book is intended to serve as a text in computer science or management studies for a senior course at undergraduate level or for postgraduate study. All chapters are appropriate for study but a few chapters - such as those on protection of proprietary software, data protection legislation and the case 
studies - can be read as separate self-contained studies. The chapters have some overlap but this is intentional because students must appreciate that the many and various security methods complement each other and that no one method can satisfactorily handle the security problems handled by other methods.

The would-be designer needs to appreciate many methods from a number of different chapters. In this sense, the chapters are purely artificial boundaries constructed to help the reader to approach a large subject.

\section{Teaching}

Security is not only a fascinating subject in its own right but is also an ideal vehicle to demonstrate the interactions between people and technology in sociotechnical systems. Ideally, the teaching of security should reflect the multidisciplinary nature of information processing and security. Therefore, it presents a perfect opportunity for team teaching.

Although every effort has been made to eliminate errors, some will inevitably remain. Therefore, I would be grateful to receive comments from readers regarding errors of a typographical or a substantive nature. 


\section{Acknowledgements}

Figures 1.1 and 1.2 are adapted from figure 7 of block II of the Open University course T301 - Complexity, management and change; applying a systems approach, Open University, 1984

Figure 3.2 is adapted with permission from figures $1 \mathrm{a}$ and $1 \mathrm{~b}$ of the paper 'Data security' by Dorothy Denning and Peter Denning, September 1979, ACM Computing Surveys. Copyright 1979, Association for Computing Machinery, Inc.

Figure 8.2 and tables 8.2 and 8.3 are reprinted by permission of the publisher from 'Security risk management in electronic data processing systems' by R. H. Courtney presented at the AFIPS National Conference 1977

Figure 8.4 is reprinted from Systems Thinking and Systems Practice by Peter Checkland. Copyright (1981) reprinted by permission of John Wiley \& Sons, Ltd.

Table 10.4 appeared in 'Computing and reform of copyright protection' by D. J. Grover and R. J. Hart, Computer Bulletin, March 1982 and is reprinted with permission of the British Computer Society

Tables 11.1, 11.2 and 11.3 appeared in the Computer Fraud Survey 1985 and are reprinted with permission of the Controller of Her Majesty's Stationery Office.

Ideas for this book started well before I received the assignment to write it. The interest in security started during the late 1960s when I was data processing manager in the Joseph Lucas Group with responsibility for designing and operating secure payroll and other financial systems. The interest developed over the next decade, first through consultancy assignments in many industries including the financial sector, later through experience of project management of major projects in the public sector and finally through my lecturing in security.

Consequently, I have learned a great deal from many people with whom I have worked and am most grateful to those who have helped directly and indirectly with my work in security. In particular, I would like to thank John Corcoran of National Giro Bank, Frank Davies of Littlewood Mail Order computer services, Mark Kahrs of the Computing Science Research Center, AT \& T Bell Laboratories, New Jersey, John Step of the Audit Consortium of the Brighton, Tunbridge Wells, Eastbourne and Hastings Health Authorities and Frank Wright of Southern Water Authority for reading parts of the book and providing helpful comments, and Peri Loucopoulos of UMIST for encouragement during the preparation of the manuscript. I have received help from many colleagues at North East London Polytechnic; in particular Allan Cheatham and John Peacham have commented 
upon parts of the book, Bill Smith helped with the use of word processors, Joan Mouyia assisted in locating publications and Gloria Shayler produced the artwork. Recognition and thanks are due to several talented and helpful members of the staff of Macmillan. In particular I would like to acknowledge the help of Bill Perry and Malcolm Stewart. Finally, and most important, the support and encouragement of my wife Joan was indispensable. 